\title{
PROSES KONSTRUKSI MAKNA DALAM BAHASA JAWA DAN INDONESIA
}

\author{
Deli Nirmala \\ Fakultas Ilmu Budaya Universitas Diponegoro \\ email: deliundip@gmail.com
}

\begin{abstract}
Abstrak
Penelitian ini bertujuan mendeskripsikan proses konstruksi makna dalam bahasa Jawa dan bahasa Indonesia. Teori yang digunakan adalah linguistik kognitif. Sumber data penelitian adalah penggunaan bahasa baik tulis maupun lisan, antara lain surat kabar, buku peribahasa Indonesia dan Jawa, dan percakapan. Pengumpulan data menggunakan metode dokumentasi dan reflektif-introspektif. Analisis data menggunakan metode referensial dan inferensi abduktif. Berdasarkan hasil analisis dapat disimpulkan bahwa makna dikonstruksikan berdasarkan pengalaman yang terkandung dalam pikiran manusia melalui proses konseptualisasi. Ada beberapa fakta yang dapat menunjukkan bagaimana makna itu dikonstruksikan, misalnya ungkapan-ungkapan metaforis, peribahasa, bentuk derivasi, tiga metafungsi bahasa, dan berbagai penggunaan bahasa dalam situasi yang berbeda.
\end{abstract}

Kata kunci: makna, dikonstruksikan, konseptualisasi, linguistik kognitif

\section{MEANING CONSTRUCTION PROCESSES IN JAVANESE AND INDONESIAN}

\begin{abstract}
This study aims to describe meaning construction processes in Javanese and Indonesian. It employed cognitive linguistic theories. The data sources were written and spoken languages in newspapers, books on Javanese and Indonesian proverbs, and conversations. The data were collected through the documentation and reflective-instrospective methods. They were analyzed using the referential and abductive inferential methods. Based on the results of the analysis, it can be concluded that meanings are constructed based on the experiences embodied in a human's mind through a conceptualization process. There are facts showing how meanings are constructed, for example, metaphors, proverbs, derivational forms, three language metafunctions, and a variety of language uses in different situations.
\end{abstract}

Keywords: meaning, construction, conceptualization, cognitive linguistics

\section{INTRODUCTION}

Humans use language for interaction in order to fulfill their needs. They use language for getting meals or other needs provided by other people if they cannot fulfill them by themselves. In interaction, other parties can understand them through meaning they can obtain.

Meaning is obtained from experience. Someone knows the meaning from the experience they have in communication and interaction. When they are born, babies cannot speak any single words. What they do is only listening to their caretaker or surrounding talking to each other, and sometimes they talk to them eventhough they do not understand due to their incapability of talking. In this period, babies acquire concept from the experience they have. Gradually, their 
physical properties are developing so that they can produce sounds which firstly have not been linguistically understood. They are babbling. The sounds cannot be recognized having meaning. Little by little, they can produce the conventional linguistic sounds. This is the early stage in language acquisition. The linguistic sounds produced are due to children's acquisition.

The study about meaning is not a new concern in linguistics. From structural perspective, meaning is like labelling. Meaning can be obtained by identifying its components as proposed by Nida (1975) and supported by Palmer (1981). From its components, Palmer (1981:108-114) said that an expression in this case words can be seen from its different features. A certain word has a certain meaning due to its labels. The labels are based on the natural category the meaning belongs to.

However, in this paper, meaning as a communication unit (Searle, 1977) is believed as a constructional unit. It is built in mind from the experience the humans have in life. The experience may refer to what they do in fulfilling their needs, what they feel, and how they feel, what happens to the nature, how the nature changes, and how people utilize the nature. All the experiences cause humans to create a concept embodied in their mind, shared, and conventionalized among the groups of the society, used in their interaction with other people. From the interaction, they acquire all the concepts used in their interaction from the beginning of their life.

The idea is supported by Lakoff and Johnson (1999:18) saying that meaning is constructed. Meaning is not a matter of labelling but conceptualizing. The studies about metaphors can show how meaning is constructed. With metaphors, human can indicate their attitudes in using language. They do not only have messages sent to another party as listener or reader, but they also indicate their attitudes of using such and such words. Therefore, metaphors can show that there are more than one layer of meaning in words or expressions (Kittay, 1987). If meaning is labelling, it shows that a word or expression only has one layer of meaning, that is the components of the meaning perceived. This idea implies that the context is excluded from the perception of meaning. The meaning is only derived from the words or constructions by ignoring how they are used. When they are used, is it possible to ignore the context referring to the words surrounding the other words or the context surrounding the use of the words?.

From the study conducted, it seems it is impossible to ignore the context of the words surrounding. Since they influence the meaning of the word surrounded. This paper is trying to show that in inferencing the meaning, I always consider the context, in this case, the words surrounding the word I use. By using abductive inference method, I analyzed the data to show how meaning construction happens. Based on the expression used with its context and other information got from the social experience the society has, I inferred the referent of the expression connected to the experience that the society may have in order to show how meaning is created. What happens in the mind during the process of producing words or expressions can support the evidence that meaning is a construction process.

According to Searle (1977), meaning can be derived from understanding. For example, when I speak to a person, and the person understands me, it shows that what I uttered is meaningful for the her/him. The speaker and hearer can understand each other if they use the same code or the understandable codes they use. Linguistically, they have similar knowledge concerning the rules in using the languages. The rules concern what 
linguistic behavior applied when they talk each other. Since language is convention, it has some rules of behavior in using language (Searle, 1977). The rules concern with what code they have to use in terms of the style, form, and meaning they have perceived. In another word, there are not only linguistic constraints they have but also non-linguistic ones that can influence the linguistic forms they use.

Studies on how meaning is constructed are not new due to the appearance of cognitive linguistics, among other things, a study that is conducted by Coulson (2006). With her project on cognitive science, she reviews ideas concerning how meaning is constructed. In her reviews she looks that meaning is constructed. According to her, based on the old knowledge in the mind which is transfered into new knowledge that is reflected in the words used, humans create new words. For example, the use of metaphorical expressions requires a process of using the literal meaning to be added with a new meaning that can make the former meaning is blent with the new meaning created. In her paper, she also shows how embodiment and blending theories support much the idea that meaning is constructed.

This paper, eventhough, has similar topic with the paper written by Coulson (2006), this paper gives more elaboration on the evidences that support the idea that meaning is constructed. Beside, I use two languages namely Javanese and Indonesian as the examples to explain the idea. Therefore, in this paper, I present the topics on metaphors, proverbs, three metafunctions proposed by Halliday (2004), derivational forms, and different uses of language in different situation. They will be explained in the following subtopics.

\section{METHODS}

This research can be categorized as descriptive and qualitative research since its purpose is to confirm whether meaning is constructed and its analysis is conducted qualitatively by using referential and abductive inferential methods. In this study, I would like to show some evidences that can support the idea proposed. To collect the data, I used reflective and introspective, and documentation techniques. Since I am the native speaker of the language investigated, I can use my both experiences, i.e schematic and systemic knowledge of language (Widdowson, 2007) to present the data. Schematic knowledge of language may refer to a cultural experience in using the language, it may be related to the rules of the society that must be considered in using the language, while systemic knowledge of language refers to the system of language used, i.e Indonesian and Javanese. Due to different cultural backgrounds, language has both features namely universality and specification. Its universality may refer to that all languages in the world have three aspects namely sounds, grammar, and meaning. Each aspect may indicate universality and specification. Its specification triggers the users to obey the rules conventionalized by the society in order to reach the goal, i.e getting the hearers understand what they mean. Based on the knowledge discussed before, I can produce the appropriate and sufficient data. The sampling technique used is purposive one, since I only chose the items needed, that is the items showing how meaning is constructed. In analysing the data, I used qualitative methods called referential method proposed by Sudaryanto (1993) and abductive inferential one proposed by Krippendorff (2004). The referential method is used to show the referents of the expressions in Indonesian and Javanese, while the abductive inferential method is used to elaborate how conceptualization happens showing that meaning is constructed. 


\section{RESULTS}

From the investigation made, I can present that meaning is constructed. To show how it occurs, I can show some evidences to confirm. The first evidence concerns the use of metaphors in daily interaction and communication. Besides, based on the research conducted on Javanese proverbs, the discussion supports how meaning is constructed, that will be explained in the following parts. The next is the different uses of language resulting in different domains of language use. The last is the three metafunctions of language. The data presented are in Indonesian and Javanese. The followings are the explanation.

\section{Use of Metaphors}

Metaphor, in this paper, refers to the expressions that indicate a conceptualization process. The conceptualization process happens when someone uses mind to construct a new word based on the existing word by giving it an additional meaning. The existing word becomes a word carrying an old experience, while the new word constructed becomes the carrier of the new experience. In other words, when $\mathrm{s} /$ he uses metaphorical expressions $\mathrm{s} / \mathrm{he}$ does not only use the literal meaning but also her or his attitudes and purposes of using the words or expressions. See the following example.

(1) China, India, Jepang dan ASEAN yang lebih dekat juga cenderung melesu perekonomiannya.

'China, India, Japan and ASEAN which is near also tend to weaken economy its.'

China, India, Japan and ASEAN countries which are near from Indonesia tend to have weakening economy. (SM, Kamis, 22 Agustus 2013 “Mengelola Gejolak Perekonomian")

The example (1) indicates that there is conceptualization happening in human mind. The conceptualization is triggered by the concept of weakening process of the abstract entity that is 'economy'. 'Economy' is considered [-concrete] so it is not visible. However, with the word melesu (weakening), it can be inferred that the user is trying to make it concrete as the concrete entity is. If it is concrete, it will be visible. The word melesu is considered metaphorical since it is combined with the word perekonomiannya. If the word is combined with the expression (1a) karena kurang darah, orang itu melesu. The word melesuin (1a) is not considered metaphorical. The question is why the writer used the word melesu instead of melemah. It can be inferred that in melesu there is an additional meaning which the word melemah does not have. To show the difference between the word melesu and melemah, I provide semantic features of both words below.

$\begin{array}{ll}\text { melesu } & \text { melemah } \\ \text { +concrete } & \text { +concrete } \\ \text { +condition } & \text { +condition } \\ \text { +for concrete entity } & \text { +for concrete entity } \\ \text { +for animate } & \text { +/-for animate } \\ \text { +more visible process } & \text { +/-visible process } \\ \text { +living } & \text { +/-living }\end{array}$

From the componential analysis, it can be seen that the word melesu indicates the concept of more visible and more specific process than the word melemah. I can say 'karena gas dalam tabung mulai habis, api dalam tungku kompor gas itu melemah; karena kurang darah, tubuh orang itu melesul melemah. However, I can not say pohon itu melesu; I can not say either api itu melesu or binatang itu melesu.

From the characteristics of both words, it can be inferred that there is a concept of strengthening in the word melesu but not in melemah. It seems there is an association process in the mind of the speaker when using the word melesu. S/he is trying to associate a condition of an animate entity like human with the condition of 
economy that is melesu. The concept of melesu for human becomes old knowledge of the speaker then it is transferred to the concept of economy that becomes new knowledge. It seems there is an active process in the mind. Therefore, in using the word melesu, it can be inferred that the speaker does not only label the entity but also construct the concept in the mind. From the example (1), it can be derived that there is a metaphor ECONOMY IS A CONCRETE, ANIMATE, AND LIVING ENTITY.

The imagination of the relatedness between the old experience and the new one supports the creation of the same word form with different concept in terms of its semantic property. There is an additional meaning property of the word. For instance, in the old experience, the word melesu has a meaning property 'concrete and animate', while in the new experience, the concept of the word is 'abstract' to have a concept of 'concrete' property. Instead of having the word like melemah, the user used melesu, since melesu has a stronger sense than melemah, and melesu includes the property of 'animate and living'. In another word, the concept of melemah is included in the concept of melesu.

In metaphors it can be seen that there are two concepts represented, namely source domain and target domain. Usually the source domain is an abstract or old concept which may be difficult to interpret; it must be explained by using another concept which is more concrete, that can make its meaning easier to understand. In metaphors, there are different consepts used to explain another concept. Different types of metaphors lead to different concepts built in the human mind when humans are interacting and communicating with others. What they experience and find in their surrounding becomes their knowledge stored in the mind called schemata (Widdowson, 2007), and the schemata which is structured becomes frames (Widdowson, 2007). The schemata is used or activated based on the mental lexicon (Kess, 1987) they have to produce a new expression. This can lead to human creativity proven by the developing of the words or expressions. For example, the words internet, situs (site), mouse adopted and adapted or borrowed by Indonesian to enrich Indonesian vocabulary. The adaptation may be done by using the meaning of the words.

The creation of the new words shows that human uses his old experience transfered to new experience. See how the word babu rakyat, memerangi kultur berokrasi, kroni-kroni, and meminggirkan used in the following example.

(2) Jika birokrasi pemerintah didorong menjadi "babu rakyat", seberapa jauh kekuatan duet ini untuk memerangi kultur birokrasi yang melingkarkan kronikroni dan meminggirkan kemurnian kompetensi? (SM, 23 August 2013 in "Semangat Baru Jawa Tengah)

If the government bureucracy can be supported to be babu rakyat, how strong can the governor and the vice governor defeat the bureucracy which more prioritizes crony or friend than someone's competence?

The concept of babu rakyat, for example, can be derived from the old concept referring to $b a b u$ or servant, transferred to the new concept of the government who is willing to serve what the people or the society want. The concept of memerangi may imply that bureucracy is conceptualized as a battlefield, and the concept of meminggirkan may imply that competence purity belongs to concrete entity. The word meminggirkan will not be metaphorical if it is combined with the word mobil or kendaraan or any concrete entity but it is metaphorical when it is combined with kemurnian kompetensi. 'Mobil' (car), or 'kendaraan' (vehicle) is 
concrete, while 'competence purity' is abstract. This shows that there is a process of changing the abstract concept kemurnian kompetence to concrete one.

The use of the words in (1) and (2) above may be the examples of the belief that metaphor has more than one layer of meaning. According to Kittay (1987); Hidasi (2008:107), metaphors have first and second order of meaning.

\section{Use of Proverbs}

Proverbs are rich of social, cultural, spiritual, and even ideological values. They are in the forms of phrases or groups (Halliday, 2004), clauses, and sentences. Javanese proverbs, for instance, can be classified into metaphorical and nonmetaphorical. In terms of their form, the metaphorical proverbs have similar characteristics to those which are nonmetaphorical. However, in terms of their concept, metaphorical proverbs indicate conceptualization, i.e explaining a concept with another concept. For example, the proverb aja rumangsa bisa ning bisaa rumangsa (don't claim that you can be or do anything but you have to realize your weakness or incapability) can be categorized non-metaphorical, while the proverb ajanggugah macan turu (don't make a sleeping tiger awake) can be categorized metaphorical due to the use of the word tiger which is conceptualized as a person who is very strong and powerful.

From the values represented by the proverbs, I can give an example of the proverbs like alon-alon waton kelakon 'slow but sure', in Javanese, which represents 'patience', 'commitment', 'care', 'attentiveness', and 'best quality'. The proverb indicates the perception and attitude of the Javanese society in completing work or reaching goals. The society perceives that any action completing work or reaching goals needs a process. The process must take time and energy.
The use of proverbs can also be an evidence that meaning is constructed. The proverbs contain people's ideals or dreams in creating harmonious life among individuals, groups, or even life in relation with God. For example, the Javanese proverb narimo ing pandum (you must accept what you get) indicates the local wisdom of the Javanese society, saying that in life, people must deeply accept what they have got, eventhough they must struggle to achieve their goal. When they do not succeed in getting their goals, they must narimo ing pandum, meaning that they must be ikhlas or accept what God has given.

The local wisdoms that can be represented by the concept in Javanese proverbs are related with among other things work spirit, leadership, honesty, self restraint. The local wisdom may affect Javanese perception, behavior, attitude, and personality in facing life problems. This can help the Javanese to be fair towards themselves or others'. For example, in dealing with other people they will be more patient if they have something to achieve.

From the examples above, the meaning of the expressions is constructed by conceptualization. It is not only a matter of labelling but also constructing. The process of constructing meaning is triggered by the experiences embodied and stored in the mind. Therefore, constructing meaning means conceptulizing an old concept to a new one.

\section{Derivational Forms}

In aglutinating languages, like Indonesian and Javanese, derivational morphemes can be one of their characteristics, that can show the process of developing words. The number of the words becomes increasing, since by this process, getting new words can be created, that lead to different word categories or different meanings depending on the 
use of the words. For example, the word baik can be categorized into an adjective, but when it is attached with ((mem-) $(-k a n))$ to become the word membaikkan in membaikkan orang lain, the derivational form membaikkan can be grouped into a verb. In using membaikkan, there is a process of conceptualization which indicates a process of changing something from a certain condition to another condition. So, the word baik means good, while the word membaikkan means a process of changing to someone to become better. Another example can be seen from the following.

(3) Konglomerat bisa menghitamputihkan perekonomian Indonesia.

The verb menghitamputihkan in (3) indicates that conglomerate can change the Indonesian economy into a better or worse condition. The word menghitamputihkan can be derived from hitam 'black' combined with putih 'white' then attached to the confix (me-kan). The resulting form menghitamputihkan indicates that there is a process of changing from a certain condition to another one. It can be assumed that there is an agent that can make something change. Besides, there are two different conditions changed.

The use of the word menghitamputihkan indicates that there is an intention of the user to use the word instead of another word, for example the word or expression mengubah dari yang baik menjadi jelek dan yang jelek menjadi yang baik to represent his concept. The idea of using the word is drived by the conceptualization based on the knowledge stored in the mind derived from the existing experience concerning the concept of color. In this example, the concept of 'black' and 'white' is given additional meanings 'bad' and 'good' respectively. The derivational morpheme (me-kan) becoming (meng-kan), when attached to the construction hitam putih, refers to the concept of changing.
Another example can be presented here is the word dimiskinkan in para koruptor seharusnya dimiskinkan. The word miskin means poor; when it is attached to the morpheme (di-kan), its meaning changes into the process of making someone to be much poorer as sufferer as experienced by the poor. The word dimiskinkan does not only refer to the loss of the wealth own by the corruptor but also the changes of the psychological conditions the corruptor has.

Another derivational form is dipinggirkan in ...amanah yang dipinggirkan dalam kasus kuota impor daging. The word dipinggirkan indicates that there is a process of adding the meaning of the word. The derivational process triggers the changing of meaning. There is a conceptualization process towards the concept of amanah 'responsibility.' In this case, responsibility is considered as a concrete entity which can be moved from one place to another one.

Another examplejujuryang tersingkirkan indicates that jujur is conceptualized as a concrete entity which can be removed. The conceptualization indicates that there is an active process in the mind before the word is used.

\section{Three Metafunctions of Language}

Dealing with meaning, we can see from different points of view proposed by Halliday (2004) discussing meaning from semantic and grammatical points of view. I think he believes that meaning is built when a word is constructed with another word. Constructing words into larger units can create context that can support meaning. Meaning can be derived not only from its literal meaning derived when it is in isolation, but meaning can be derived through wording system or grammatical system. Therefore, Halliday shows that a construction called a clause may have three metafunctions simultaneously, i.e ideational, interpersonal, and textual. 
When used in communication, a word is combined with another word. Halliday (2004) differenciates two kinds of clauses namely minor clauses and major clauses. The difference is caused by predication. Halliday (2004) differenciates minor clauses from major clauses. The minor clause refers to the expressions for phatic communion like selamat pagi or pagi uttered by someone meeting others in the morning; assalamualaikum used for greeting, bagus itu for complementing, selamat ya for congratulating, etc; while the major clauses refer to the expressions having subject and predicate and having a complete idea.

In Indonesian, a clause nanti malam ada undangan di tetangga sebelah 'there is an invitation from the neighbor next to us', has three metafunctions simultaneously, i.e refering to the existence of a certain event, being used for inviting the interlocutor, and being spoken because the speaker has relation with the interlocutor.

\section{Different Uses of Language Resulting in Different Language Variations}

Different language variations can be identified from any uses of language due to different regions, social groups or ethnicities, fields of study, domains, etc. The use of addressing forms, honorifics, for example, may indicate different concepts used. In Indonesian, in family domain, for example, I can find the use of ibu, bapak, mama, papa, rama, adik, kakak, eyang, pakde, bu De, pak Lik, bu Lik. Different forms may be found due to different cultures or ethnicities. In Javanese society, the addressing forms used are among other things ibu, bapak for mother and father respectively. Nowadays, the use of mama and papa is more dominant than that of $i b u$ and bapak to call mother and father respectively. Similar forms may also be used for different purposes. For example, the words ibu, bapak, and eyang (grandmother), beside they are used due to kinship relation, they are used for calling elder people. Ibu is used for elder women, bapak is used for elder men. Besides, the use of both vocatives -ibu and bapak are for respecting the elders female and male.

From this phenomenon, I can see that addressing forms as an example of refering expressions may indicate a reason for using different forms. People use mama only for calling their mother, but they use $i b u$ beside for calling their mother they use it for elder people. When calling a person, there is attitude influencing the decision in choosing the appropriate form. For example, if someone calls an elder woman with mama he conceptualizes that the elder woman has the same characteristics as his mother. Besides, he wants to show that he has close relationship with her. It is like when he is with his mother.

\section{Different Domains: family and work}

Family domain may result in its members' relationship namely kinship system. The relationship between children and parents are different from that between husband and wife. The relationship among children is different from that among elders. In addition, at work, people have relationship like superordinate and subordinate, and the relationship among colleagues. Between superordinate and subordinate, they have more and less power; while among colleagues, they have equal relation meaning equal power.

In different domains, people tend to use different styles that can be identified segmentally and grammatically. From its segmental point of view, style can be identified from the words used. For example, in Indonesian, if I say " $A k u$ akan pergi (I will go)" is considered less formal than "Saya akan pergi (I will go)". From grammatical point of view, style can be seen from its construction. The same content may be expressed in different forms or the same form may be used for different contents or functions. 
In using different words, in their mind, people think of many aspects, for example, that they choose saya instead of $a k u$ indicates a reason why they choose certain word instead of the others conveying the same meaning. When they talk to a person, they think who they are speaking with, what relationship they have, in what occasion they speak, etc.

Different Fields of Study: medicine, linguistics, economics, laws, psychology, etc. In linguistics, for example, the word like construction refers to language form consisting of morphemes or words, phrases, clauses or sentences. However, in engineering, construction refers to building consisting of concrete, column, sand, bricks, pilars, etc. People from different fields of study have different experiences in the field they belong to. The experiences are embodied and stored in their mind, which lead to meaning construction. For example, why do people use the same word for different referent?. This can be inferred that they have different experiences. For example, linguists study language, while engineers study building. They have different worlds that can reflect in using language.

Different Users with Different Backgrounds: age, region, gender, rank, etc. Language variation due to its different regions is called dialects; people from Nusatenggara will use different dialects of Indonesian from the people from Java. For example, the use of beta is to identify the speaker, that can be found in East Indonesian, for example Flores, while the use of gue is to identify the speaker, that can be found in Jakarta and its surroundings. Beta and gue are the variation of saya ' $\mathrm{I}$ '. They are different due to the speakers' different background. When someone from a certain dialect is speaking with someone from another dialect, she or he will adjust himself to the speaker speaking with. He or she will be able to recognize the speaker's region of origin. If the speakers are not in mutual intelligibility (Hockett, 1958), they will find a code which can make them interact and communicate and reach their communication goals. There is a possibility for them to change their code. The adjustment process is not arbitrarily done, it is purposive in order to make the communication run well. If there is a communication gap due to different systems of language, they try to use the code or means in which the participants can communicate each other.

The question is why people use different forms for the same content. They have different experiences in life. To identify how different people from different regions speaking different accents can be done by using dialectal method. Empirically, I can present an example. When I had a mate from Purworejo, Central Java, while I am from Madiun, East Java, I sometimes misunderstand her because I and my mate use different words for the same concept. At that time, I was sunning my pillow, and it was drizzling, so I asked her to pick up the pillow by saying dientas bantale 'pick up the pillow', but she did not understand me. As a result, she did not pick up the pillow. Then, I asked her why she did not pick up the pillow, and she said that she did not know that pillow is bantal in Javanese. In her language, to say 'bantal' she uses lempir.

\section{Different Situation}

Language is used in different situation like at home, school, office, court. In formal situation, the language used is different from the language used in informal situation. For example, the language used in a meeting among the executives of a company will be different from the language used in a restaurant.

From some evidences shown in the previous explanation, I may say that different uses of language indicate different purposes or intention. When 
someone uses a certain form, he has intention why he uses such form instead of the other forms. Sometimes, the same form may be used for different purposes. Like what I explained before, someone uses the word $i b u$ for calling his own mother and for calling another woman older or someone he or she respects. He uses the same word but different referents. It seems, there is conceptualization in his mind that the elder woman, in some points, has similarities. Besides, it is used for showing that he has close relationship, he places himself as someone as her child, someone that must be cared for. In this case, there is something common used for an entity which is specific. The common meaning of $i b u$ refers to all women older than the speaker and or married, but the specific meaning of $i b u$ refers to the speaker's own mother. If I can draw a diagram, it can be like this.

$\mathrm{Ibu} \rightarrow$ common meaning: all women older than the speaker

$\rightarrow$ specific meaning: the speaker's mother

When using the word $i b u$, the speaker is conceptualizing the figure of the woman talking with is his mother, and he expects that she will grasp the same intention that he would be her son or someone close with her.

\section{Human Creativity}

Some evidences explained above also support that human uses his creativity in using language. The creativity is not only a matter of number but it also refers to meaning. In human hands, a word can be anything. In terms of its form, a word has the same form, but in terms of its meaning, it has many different meanings. Even in its form, a word can be developed in terms of its number of its elements building the construction, or the meaning conveyed by the form.

\section{CONCLUSION}

From the analysis, I can conclude that meaning of the linguistic units can be derived from both labelling and constructing. As proposed by Nida (1975), labelling can be done by depicting the semantic features conventionalized by the users of the language. However, constructing is believed as conceptualizing. Conceptualization is conducted through the use of the experiences in using language in interaction and communication with other people. Conceptualization is based on the old experience or knowledge in the mind used to construct a new concept of words or expression.

\section{REFERENCES}

Coulson, S., 2006. “Constructing Meaning". Metaphor and Symbol. vol 2/(4), pp. 246266. Lawrence Erlbaum Associates, Inc. http://www.cogsi.ucsd.edu/ coulson/ Papers/constructing-meaning. pdf downloaded on Thursday, 20 November 2014 at 5.32

Halliday, M.A.K., 2004. 3rd Edition. An Introduction to Functional Grammar. New York: Oxford University Press.

Hidasi, Y., 2008. "Cultural Messages of Metaphors". Edited by Erich A Berend in Metaphors for Learning. Amsterdam: John Benjamins Publishing Company, pp. 103-122

Hockett, C.F., 1958. A Course in Modern Linguistics. New York: the Macmillan Company

Kittay, E.F., 1987. Metaphor: Its Cognitive Force and Linguistic Structure. Oxford: Clarendon Press.

Krippendorff, K., 2004. Content Analysis:An Introduction to Its Methodology. California: Sage Publications, Inc.

Lakoff, G. and Mark J., 1999. Philosophy in the Flesh: The Embodied Mind and its Challenge to Western Thought. New York: Basic Books

Nida, E.A.,1975. Componential Analysis of Meaning. Paris: Moutan-the Hague 
Palmer, F.R., 1981. Semantics. Cambridge: Cambridge University Press

Searle, J.R., 1977. Speech Acts. Cambridge: Cambridge University Press.

Sudaryanto, 1993. Metode dan Aneka Teknik Analisis Bahasa. Pengantar Penelitian
Wahana Kebudayaan secara Linguistis. Yogyakarta: Duta Wacana University Press.

Widdowson, H.G., 2007. Discourse Analysis. Oxford: Oxford University Press 